\title{
PROSES BERPIKIR KREATIF MATEMATIK PESERTA DIDIK MENURUT WALLAS DALAM MEMECAHKAN MASALAH OPEN-ENDED DITINJAU DARI SELF-REGULATED LEARNING
}

\author{
*Herni Indriastuti \\ SMK Negeri 1 Rajadesa, Tasikmalaya, Indonesia \\ *Email Korespondensi: indria.herni@gmail.com
}

INFO ARTIKEL

Diterima 19 Juli 2021

Dipublikasikan 31 Juli 2021

\begin{abstract}
ABSTRAK
Penelitian ini dilakukan untuk mendeskripsikan proses berpikir kreatif matematik peserta didik dalam memecahkan masalah open-ended pada materi perbandingan trigonometri. Penelitian ini adalah penelitian deskriptif kualitatif, sedangkan metode yang digunakan dalam penelitian ini adalah metode tes dan wawancara. Tes dan wawancara dianalisis untuk mendeskripsikan proses berpikir kreatif peserta didik yang berpandu pada model Wallas yang meliputi tahap persiapan (preparation), inkubasi (incubation), iluminasi (illumination), dan verifikasi (verification). Semua peserta didik dianggap mampu memecahkan masalah openended dengan caranya sendiri dan tidak terpaku pada satu jawaban karena dalam proses penyelesainnya bervariasi melalui berbagai macam alternatif cara. Hasil penelitian menunjukan bahwa $S_{1} S_{2}, S_{3}$ memiliki proses berpikir kreatif tinggi karena bisa melewati tahap persiapan, inkubasi, iluminasi dan verifikasi yang baik, walaupun terdapat satu subjek yaitu $S_{2}$ yang dianggap cukup dalam tahap verifikasi yang berupa proses penyimpulan masalah. Bahkan ada satu subjek yaitu $S_{4}$ yang dianggap berkemampuan sedang karena bisa melewati tahap persiapan dan inkubasi dengan baik sedangkan tahap iluminasi dan verifikasi cukup. Hasil penelitian $S_{5}$ merupakan peserta didik berkemampuan rendah karena hanya melewati setiap tahap dengan kurang.
\end{abstract}

Kata Kunci: berpikir kreatif, open-ended, self-regulated learning, wallas

\section{MATHEMATICS CREATIVE THINKING PROCESS OF STUDENTS ACCORDING TO WALLAS IN SOLVING PROBLEMS OPEN-ENDED BASED ON SELF-REGULATED LEARNING}

\begin{abstract}
This research was conducted to describe students' mathematical creative thinking process in solving open-ended problems in trigonometric comparison material. This research is a qualitative descriptive study, while the methods used in this research are test and interview methods. Tests and interviews were analyzed to describe the creative thinking process of students guided by the Wallas model, which includes the preparation, incubation, illumination, and verification stages. All students are considered capable of solving open-ended problems in their way and are not fixated on one answer because the solution process varies through various alternative ways. The results showed that $S_{1}, S_{2}, S_{3}$ had a high creative thinking process because they could pass the preparation, incubation, illumination, and verification stages well. However, there was one subject, namely $S_{2}$, which was considered sufficient in the verification stage in the form of a problem-solving process. Even one subject, namely $\mathrm{S}_{4}$, is considered moderately capable because he can pass the preparation and incubation stages well, while the illumination and verification stages are sufficient. The results of the $S_{5}$ research are students with low abilities because they only pass each stage with less.
\end{abstract}


Keywords: creative thinking, open-ended, self-regulated learning, wallas

\section{Pendahuluan}

Pengembangan proses berpikir kreatif saat ini telah menjadi salah satu fokus pembelajaran yang sangat penting untuk dikembangkan, dikarenakan peserta didik sering menghadapi kesulitan dalam menyelesaikan berbagai macam soal. Oleh karena itu dalam penyelesaian soal sangat dibutuhkan proses berpikir kreatif karena dengan adanya proses berpikir kreatif peserta didik dituntut agar dapat menyelesaikan dan mengembangkan jawaban dari berbagai macam alternatif cara.

Setiyani (2013) menyatakan bahwa proses kemampuan berpikir kreatif seseorang diperlukan untuk mengembangkan ilmu pengetahuan dan teknologi serta menjadi penentu kesuksesan individu dalam menghadapi tantangan kehidupan yang semakin kompleks. Pehkonen dalam Siswono (2010) mengatakan proses berpikir kreatif matematis merupakan kombinasi dari berpikir logis dan divergen yang didasarkan pada intuisi namun masih dalam tahap kesadaran. Ketika peserta didik menerapkan berpikir kreatif dalam memecahkan masalah, maka dari proses berpikir tersebut dituntut dapat menghasilkan ide atau gagasan baru. Martin (2009) mengemukakan bahwa, proses kemampuan berpikir kreatif adalah suatu kemampuan dalam menghasilkan ide atau cara baru dalam menghasilkan sesuatu. Upaya dalam menumbuhkan suasana kreatif, guru dapat melakukan suatu kegiatan yang dapat membuat peserta didik menjadi aktif dalam proses berpikir. Peserta didik dituntut mengerjakan soal melalui pemikiran yang imajinatif dengan berbagai macam alternatif cara.

Analisis proses berpikir kreatif peserta didik telah dilakukan oleh beberapa peneliti sebelumnya. Para peneliti tersebut memiliki pedoman yang berbeda-beda untuk mengidentifikasi atau memperoleh deskripsi proses berpikir kreatif peserta didik. Dalam penelitian ini, untuk memperoleh deskripsi proses berpikir kreatif peserta didik, pedoman yang digunakan mengacu pada model Wallas yang meliputi tahap persiapan (preparation), inkubasi (incubation), iluminasi (illumination), dan verifikasi (verification) (Munandar, 2012).

Tahap persiapan diartikan sebagai tahap di mana peserta didik mempersiapkan diri untuk memecahkan masalah matematika dengan cara mengumpulkan data yang relevan untuk menyelesaikan masalah. Tahap inkubasi diartikan sebagai tahap dimana peserta didik melepaskan diri secara sementara dari masalah untuk memperoleh inspirasi yang merupakan titik mula dari suatu penemuan atau kreasi yang baru dari daerah pra sadar. Tahap iluminasi diartikan sebagai tahap dimana peserta didik mendapatkan sebuah pemecahan masalah yang diikuti dengan munculnya inspirasi dan ide-ide yang mengawali dan mengikuti munculnya inspirasi dan gagasan baru. Tahap verifikasi diartikan sebagai tahap dimana peserta didik menguji atau memeriksa pemecahan masalah tersebut terhadap realitas yang membutuhkan pemikiran kritis dan konvergen.

Salah satu cara untuk menganalisis proses berpikir kreatif adalah melalui hasil kreativitas peserta didik. Untuk memperoleh hasil kreativitas peserta didik yang tepat dapat digunakan kegiatan pemecahan masalah dengan solusi atau strategi penyelesaian tidak tunggal. Jawaban beragam dari suatu masalah dapat meningkatkan kualitas pembelajaran matematika (Stiger \& Hiebert dalam Anggraeny \& Siswono, 2012). Selanjutnya Levav-Waynberg \& Leikin (2009) juga mengungkapkan bahwa pemecahan masalah dengan strategi atau cara penyelesaian yang berbeda dapat memberikan kontribusi terhadap kreativitas dan berpikir kritis peserta didik.

Berpikir kreatif berkaitan erat dengan pemecahan masalah dalam matematika, dan khususnyapemecahan masalah kehidupan nyata yang dengan sudut pandang penyelesaian yang berbeda (Wessels, 2014). Salah satu bentuk masalah dalam matematika yang penyelesaiannya memerlukan proses berpikir tingkat tinggi adalah masalah open-ended. Hal ini disebabkan karena dalam memecahkan masalah open-ended dibutuhkan strategi dalam memunculkan berbagai alternatif jawaban.

Pemecahan masalah open-ended merupakan masalah terbuka yang memiliki banyak cara dalam penyelesaiannya. Masalah terbuka ini dikelompokkan menjadi tiga jenis, yaitu masalah yang dapat diselesaikan dengan cara bervariasi, masalah yang memiliki jawaban bervariasi, dan masalah yang dapat dikembangkan dengan cara mengubah kondisi masalah sebelumnya (Subanji, 2013). Pemberian soal 
pemecahan masalah open-ended dapat membantu guru mengevaluasi keragaman pengetahuan peserta didik dan dapat mendorong berpikir kreatif peserta didik (Nabie, 2013).

Selain dari proses berpikir kreatif, peserta didik dituntut memiliki suatu kemandirian dalam belajar (self-regulated learning). Peserta didik yang kemandirian belajarnya baik dan stabil akan mampu menata dirinya dalam belajar maupun menyelesaikan soal. Menurut Zimmerman dalam Cheng (2011) mengemukakan bahwa self-regulated learning adalah suatu proses ketika seorang peserta didik berpartisipasi aktif dalam belajar secara metakognisi, motivasi maupun perilaku. Oleh karena itu dapat dikatakan bahwa self-regulated learning bukanlah merupakan suatu kemampuan mental seperti intelegensi atau kemampuan akademis melainkan suatu proses ketika seorang peserta didik berpartisipasi aktif dalam belajar baik secara motivasi maupun perilaku. Peserta didik dikatakan memiliki sifat self-regulated learning apabila telah mampu menyelesaikan suatu permasalahan atau soal tanpa adanya ketergantungan dengan orang lain, sehingga peserta didik akan berusaha sendiri terlebih dahulu untuk mempelajari serta memahami isi pelajaran yang dibaca atau dilihatnya melalui media pandang dan dengar.

Berdasarkan uraian di atas, maka rumusan penelitian ini adalah bagaimanakah proses berpikir kreatif matematik peserta didik menurut Wallas dalam memecahkan masalah open-ended terhadap materi perbandingan trigonometri ditinjau dari self-regulated learning. Tujuan penelitian ini adalah untuk mendeskripsikan proses berpikir kreatif peserta didik dalam pemecahan masalah open-ended yang difokuskan pada proses berpikir kreatif yang berpandu pada model Wallas yang diaplikasikan pada materi perbandingan trigonometri jika ditinjau dari self-regulated learning

Hasil penelitian ini diharapkan dapat memberikan informasi bagi guru maupun calon guru sebagai bahan pertimbangan untuk melihat sisi lain dari kemampuan berpikir yang tidak sebatas pada ingatan saja, melainkan dapat dilihat dari proses berpikir kreatifnya melalui suatu soal permasalahann open-ended dalam memecahkan dan menyelesaikan suatu permasalahan, ditinjau dari self-regulated learning. Selain itu, peserta didik diharapkan mampu menyelesaikan masalah dengan caranya sendiri dan tidak terpaku pada satu jawaban tetapi bisa melalui berbagai macam alternatif cara dalam penyelesaiannya.

\section{Metode Penelitian}

Berdasarkan rumusan dan tujuan penelitian, maka jenis penelitian yang digunakan adalah penelitian kualitatif. Metode yang digunakan dalam penelitian ini yaitu deskriptif kualitatif, karena dalam penelitian ini peneliti mendeskripsikan tentang proses berpikir kreatif matematik peserta didik menurut teori Wallas dalam pemecahan masalah open-ended jika ditinjau dari self-regulated learning.

Sugiyono (2011) berpendapat bahwa penelitian kualitatif adalah penelitian yang digunakan untuk meneliti objek alamiah. Selain itu, Denzin dan Licoln (dalam Moleong, 2017) mengemukakan bahwa penelitian kualitatif adalah penelitian yang menggunakan latar belakang alamiah dengan tujuan menterjemahkan fenomena yang terjadi. Hal itu sejalan dengan penelitian yang peneliti gunakan karena penelitiannya dilakukan pada orang atau human untuk memahami suatu fenomena atau kejadian yang terjadi pada objek kemudian datanya bersifat alamiah dan tidak dimanipulasi oleh peneliti.

Selain itu, Williams (dalam Moleong, 2017) mengemukakan bahwa penelitian kualitatif adalah pengumpulan data dari latar alamiah dengan metode alamiah dan dilakukan oleh peneliti yang tertarik secara alamiah. Selanjutnya peneliti akan mendeskripsikan data tentang bagaimana proses berpikir kreatif matematik peserta didik menurut Wallas dalam memecahkan masalah open-ended terhadap materi perbandingan trigonometri jika ditinjau dari self-regulated learning.

\subsection{Subjek Penelitian}

Subjek penelitian ini diambil dari peserta didik SMK Negeri 1 Rajadesa Tahun Ajaran 2019/ 2020 semester genap sebanyak lima orang peserta didik sebagai subjek penelitian. Dari lima orang subjek tersebut diberikan tes proses berpikir kreatif peserta didik melalui pemecahan masalah open-ended. 


\subsection{Pengumpulan Data}

Cara yang digunakan dalam pengumpulan data dalam penelitian ini adalah metode tes proses berpikir kreatif peserta didik dan wawancara. Tes soal berpikir kreatif peserta didik dalam pemecahan masalah open-ended digunakan untuk mengetahui gambaran atau proses berpikir kreatif peserta didik tentang sejauhmana pemahamannya terhadap suatu soal dan mengetahui sejauhmana cara penyelesaiannya dengan menggunakan berbagai macam alternatif cara.

\subsection{Analisis Data}

Data dalam penelitian ini adalah hasil tes tertulis soal berpikir kreatif peserta didik. Sebelum dilaksanakannya kegiatan menganalisis, data diperiksa keabsahannya. Data yang diperoleh menggambarkan data yang berasal dari proses berpikir kreatif peserta didik. Proses berpikir kreatifnya dilihat pada saat peserta didik melaksanakan tes tersebut. Analisis data tes proses berpikir kreatif dalam penelitian ini bukan berupa hasil jawaban yang diperoleh dari pengerjaan peserta didik karena data yang dianalisis merupakan data kualitatif. Sehingga hasil analisis berupa gambaran atau deskripsi dari hasil proses berpikir kreatif peserta didik dalam pemecahan masalah open ended yang tertuang dalam tulisan tersebut.

\section{Hasil dan Pembahasan}

Penelitian ini bertujuan untuk untuk mendeskripsikan proses berpikir kreatif peserta didik dalam pemecahan masalah open ended yang difokuskan pada proses berpikir kreatif yang berpandu pada model Wallas yang diaplikasikan pada materi perbandingan trigonometri. Data-data hasil penelitian diperoleh berdasarkan dari tes berpikir kreatif dalam pemecahan masalah open ended yang diberikan kepada peserta didik. Setelah data diperoleh, kemudian dianalisis sata ditafsirkan sehingga menjadi deskripsi temuan dari hasil penelitian. Selanjutnya, hasil temuan dan analisis jawaban peserta didik dibandingkan dengan kajian-kajian referensi penelitian.

Dalam mencapai tujuan penelitian, peneliti mengambil subjek kelas XI SMK Negeri 1 Rajadesa sebanyak 5 orang. Waktu yang digunakan peneliti dalam melaksanakan penelitian yaitu pada bulan Nopember-Desember semester genap tahun pelajaran 2019/2020. Penelitian ini merupakan penelitian yang dilakukan untuk mengetahui sejauhmana proses berpikir kreatif peserta didik pada pemecahan masalah open ended melalui materi perbandingan trigonometri ditinjau dari self-regulated learning.

Proses berpikir kreatif sendiri dinilai menurut tahapan teori Wallas yang meliputi tahap persiapan, inkubasi, iluminasi, dan verifikasi. Pelaksanaan tes diberikan kepada peserta didik yang menjadi subjek penelitian secara perorangan. Bersamaan dengan itu, peneliti mengamati proses berpikir kreatifnya. Untuk mempermudah mendeskripsikan data hasil penelitian, selanjutnya peneliti memberikan inisial kepada masing-masing responden yaitu $S_{1}, S_{2}, S_{3}, S_{4}$ dan $S_{5}$.

Pada saat pelaksanaan tes, dilakukan wawancara secara langsung kepada peserta didik. Teknik wawancara yang digunakan adalah teknik wawancara yang tak terstruktur. Pedoman wawancara yang digunakan hanya berupa garis-garis besar permasalahan yang akan ditanyakan. Wawancara dalam penelitian ini dilakukan untuk memperoleh data tentang informasi- informasi yang tidak terdapat di dalam jawaban tertulis peserta didik. Wawancara tersebut bertujuan untuk mengetahui sejauhmana proses berpikir kreatif matematik peserta didik dalam penyelesaian masalah soal open ended dari soal aplikasi trigonometri yang diberikan yang ditinjau dari self regulated learning. Berikut paparan data hasil tes proses berpikir kreatif matematik peserta didik dalam pemecahan masalah open ended ditinjau dari selfregulated learning dengan subjek $S_{1}$ mempunyai nilai dengan predikat baik yang pada Gambar 1 ditunjukan di bawah ini. 


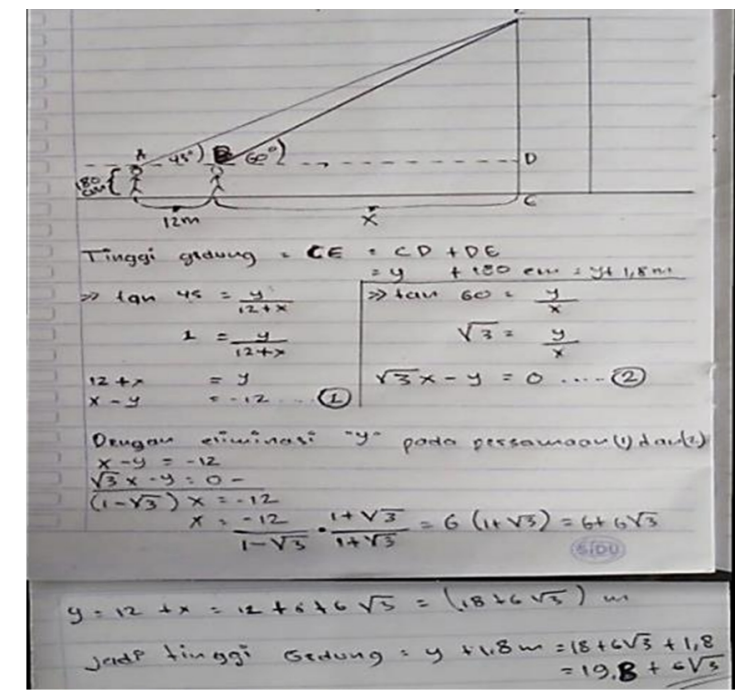

Gambar I. Jawaban Peserta Didik $\mathrm{S}_{1}$

Berdasarkan analisis data yang telah dilakukan, diketahui jika subjek $S_{1}$ termasuk kriteria peserta didik berkemampuan tinggi, karena dalam proses pemecahan masalah baik itu tes maupun wawancara, $S_{1}$ bisa memenuhi semua tahap dengan baik. Dari mulai tahap persiapan, inkubasi, verifikasi dan iluminasi peserta didik dianggap mampu menyelesaikan jawaban dengan benar dan cepat. Pada saat pelaksanaan tes, $S_{1}$ diwawancara dari mulai menganalisis soal kemudian beralih ke dalam proses gambar dan penyelesaian soal dari awal sampai akhir. Peserta didik ini bisa dikatakan benar-benar paham dalam proses menjawab soal dan ia merasa yakin akan jawaban yang dikerjakannya. $S_{1}$ dapat menganalisis soal dan mengubah soal tersebut kedalam bentuk gambar, dengan memahami hal-hal yang telah diketahui dan ditanyakan secara jelas. $S_{1}$ mampu menjelaskan dan menuliskan proses pengerjaan soal secara bertahap dan sistematis, selain itu $S_{1}$ dapat menyimpulkan hasil yang ia peroleh dengan jawaban yang benar. Hal itu jelas peserta didik dengan $S_{1}$ dianggap berkemampuan tinggi yang bisa melewati berbagai macam tahapan dari proses berpikir kreatif menurut Wallas dengan baik sampai pada proses akhir yaitu kesimpulan dengan jawaban yang benar.

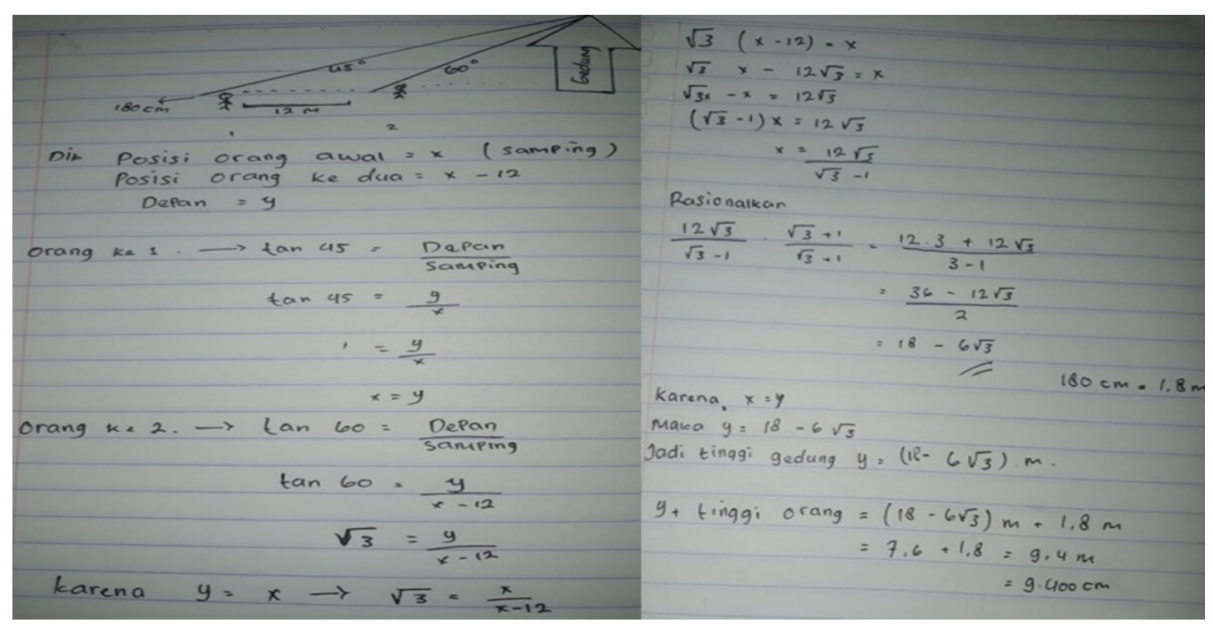

Gambar II. Jawaban Peserta Didik $\mathrm{S}_{2}$ 
Berdasarkan analisis data yang telah dilakukan, diketahui jika subjek $S_{2}$ telah memenuhi sampai fase verifikasi yaitu peserta didik dianggap mampu menyelesaikan soal dengan proses berpikir kreatifnya sendiri yang dianggap berkemampuan tinggi. Tetapi pada tahap verifikasi peserta didik yang diartikan sebagai tahap di mana peserta didik mampu menguji atau memeriksa pemecahan masalah tersebut, terdapat kesalahan sehingga jawabannya kurang tepat yaitu pada tahap proses pengambilan kesimpulan. Pada saat pelaksanaan tes, S2 diwawancara dari mulai menganalisis soal kemudian beralih kedalam proses gambar dan penyelesaian soal dari mulai tahapan persiapan, inkubasi, iluminasi dan verifikasi. Peserta didik ini bisa dikatakan dapat menjawab pertanyaan dengan baik walaupun dalam penyimpulan jawabannya terdapat sedikit keraguan. $S_{2}$ dapat memahami permasalahan yang diketahui, ditanyakan dengan proses yang jelas tetapi $S_{2}$ dianggap kurang memahami dalam proses penyimpulan jawaban. Antara proses jawaban $S_{1}$ dengan $S_{2}$ dapat dikatakan memiliki proses pemecahan masalah open-ended, di mana antara kedua subjek terdapat cara penyelesaian jawaban yang bervariasi. Hal ini jelas bahwa soal pemecahan open-ended dapat dilakukan dalam berbagai alternatif cara, walaupun prosesnya berbeda tapi apabila cara itu benar maka hasilnya pasti sama. Proses berpikir kreatif $S_{2}$ disana dikatakan proses berpikirnya tinggi walaupun dengan hasil akhir yang kurang tepat.

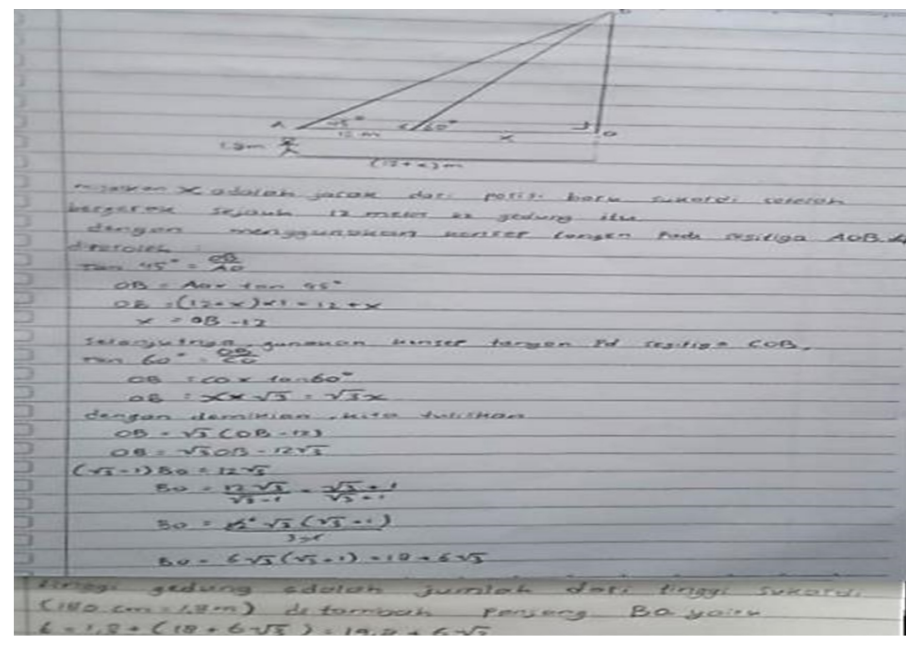

Gambar III. Jawaban Peserta Didik $\mathrm{S}_{3}$

Berdasarkan analisis data yang telah dilakukan, diketahui jika subjek S3 telah memenuhi sampai pada tahap verifikasi yaitu peserta didik dianggap mampu menyelesaikan soal dengan proses berpikir kreatifnya sendiri. Dari mulai tahap persiapan, inkubasi, iluminasi dan verifikasi S3 dianggap mampu mempersiapkan diri untuk memecahkan permasalahan matematika dengan baik.. Pada tahap inkubasi S3 dianggap mampu dalam memperoleh inspirasi yang merupakan titik mula dari suatu gambar yang diaplikasikan ke dalam sebuah proses berupa tulisan. Pada tahap iluminasi S3, dianggap mampu mendapatkan sebuah pemecahan masalah yang diikuti dengan munculnya inspirasi dan ide-ide yang mengawali dan mengikuti munculnya inspirasi dan jawaban-jawaban yang benar, walaupun pada saat memasuki tahap ini sempat bingung dalam menyelesaikan jawabannya. Pada tahap verifikasi diartikan S3, peserta didik ini dianggap mampu menguji atau memeriksa pemecahan masalah dengan hasil kesimpulan yang benar. Pada saat pelaksanaan tes, S3 diwawancara dari mulai menganalisis soal kemudian beralih ke dalam proses gambar dan penyelesaian soal, peserta didik ini benar-benar mengerti dari mulai apa yang ditanyakan, diketahui sampai dalam proses dan pengambilan kesimpulan, walaupun dalam proses wawancaranya S3 dianggap tidak seyakin S1. S3 dapat dianggap memiliki proses berpikir kreatif berkemampuan tinggi dalam pemecahan masalah open ended karena memiliki pemahaman yang baik terhadap menjawab soal secara sistematis dan jelas. 


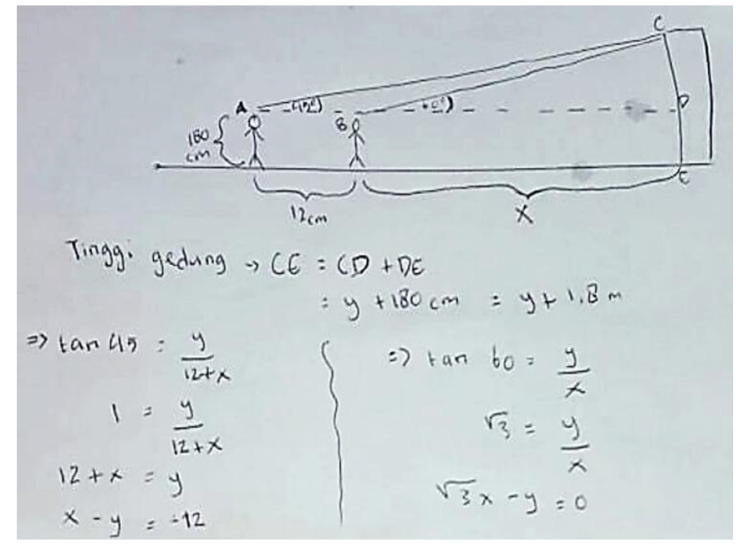

Gambar IV. Jawaban Peserta Didik $\mathrm{S}_{4}$

Berdasarkan analisis data yang telah dilakukan, diketahui jika subjek $S_{4}$ berhasil mengerjakan soal dengan baik. Pada tahap persiapan $S_{4}$ sudah paham maksud dari soal tersebut, sehingga ia tidak mengalami kesulitan dengan mengubah soal ke dalm bentuk gambar dan perbandingan. Pada tahap inkubasi, $S_{4}$ benar-benar paham apa yang ditanyakan, diketahui maupun proses penyelesaian masalah, tetapi memasuki tahap iluminasi tentang bagaimana cara mengerjakan soal ke proses perbandingan, dia benar-benar merasa cukup yakin tentang proses yang harus ia lakukan. Tetapi setelah penulis teliti $S_{4}$ hanya mampu menyelesaikan sebagian dari jawaban yang harus dikerjakan. $S_{4}$ merasa bingung dalam menentukan kesimpulan sehingga $S_{4}$ dapat dikatakan peserta didik yang memiliki kemampuan sedang yaitu bisa melewati tahap persiapan dan inkubasi dengan baik, sedangkan dia tidak bisa melewati tahap iluminasi dan verifikasi dengan baik.

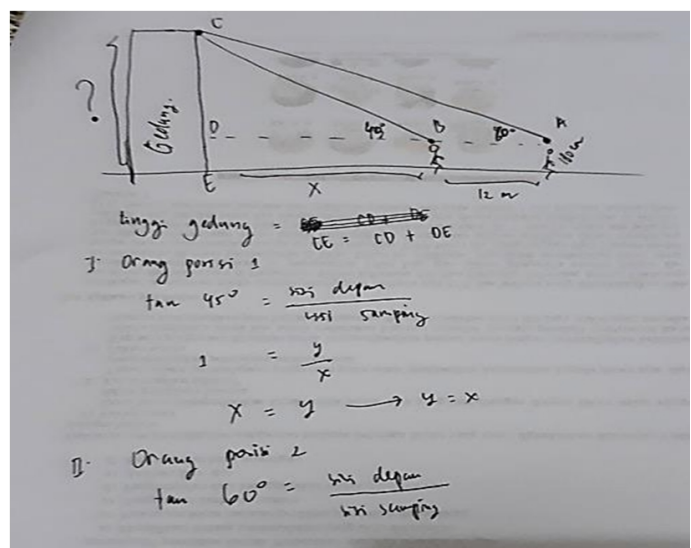

Gambar V. Jawaban Peserta Didik $S_{5}$

Berdasarkan analisis data yang telah dilakukan, diketahui jika subjek $S_{5}$ kurang memahami soal dengan baik. Pada tahap persiapan $S_{5}$ cukup paham maksud dari soal tersebut, tapi terdapat sedikit kesalahan dalam pemahaman penempatan angka pada gambar. Pada tahap inkubasi $S_{5}$, ditanya apa yang diketahui, ditanyakan dalam soal dan peserta didik tersebut ternyata kurang memahami soal yang telah diberikan. Sedangkan, pada tahap iluminasi dan verifikasi $S_{5}$, mengalami kesulitan dalam menjawab soal, sehingga dia merasa benar-benar tidak mampu untuk mengerjakan soal tersebut. $S_{5}$ dapat dikatakan memiliki kemampuan berpikir kreatif rendah karena dia hampir melewati setiap tahap dengan kurang.

Berdasarkan hasil tes, wawancara dan hasil pengamatan terhadap subjek, temuan dari penelitian ini adalah sebagai berikut:

a. Subjek dengan kemampuan matematika tinggi, cenderung mampu melakukan setiap langkah proses berpikir kreatif dengan baik, walaupun ada sedikit kesalahan dalam mengerjakan soal. Peserta didik 
mampu berpikir dan mencurahkan ide-ide untuk mengerjakan soal. Subjek berkemampuan matematika tinggi terbukti lebih baik dalam mengerjakan soal daripada subjek berkemampuan matematika sedang dan subjek berkemampuan matematika rendah.

b. Subjek dengan kemampuan matematika sedang, juga sudah melakukan setiap langkah proses berpikir kreatif dengan cukup baik. Peserta didik saat diwawancarai bisa

menjawab pertanyaan dengan baik dan dengan bahasanya sendiri. Walaupun ada kesalahan saat mengerjakan soal.

c. Subjek dengan kemampuan matematika rendah, cenderung belum dapat melakukan setiap langkah proses berpikir kreatif dengan baik. Peserta didik tidak mampu memahami permintaan tugas dengan baik.

Beberapa temuan lain yang terdapat dalam penelitian ini adalah saat peserta didik mengalami kesulitan dalam menyampaikan pendapatnya, peserta didik cenderung kurang teliti dalam mengerjakan soal dan peserta didik sebenarnya paham maksud soal tapi tidak bisa mengerjakannya dengan benar

\section{Kesimpulan}

Berdasarkan hasil analisis data dari $S_{1}, S_{2}, S_{3}, S_{4}$ dan $S_{5}$, tentang proses berpikir kreatif matematik peserta didik dalam pemecahan masalah open-ended ditinjau dari self-regulated learning. Peserta didik yang diambil sampel dari beberapa kelas yaitu kelas XI jurusan TKRO, dapat diambil suatu kesimpulan bahwa proses berpikir kreatif peserta didik kelas XI TKRO umumnya dapat dikatakan baik. Peserta didik dalam pelaksanaan penyelesaian soal dapat memenuhi 4 tahap dari teori Wallas yaitu tahap persiapan, inkubasi, iluminasi dan verifikasi. Berikut ini adalah kesimpulan hasil peserta didik yang disusun dalam bentuk tabel, yaitu sebagai berikut :

Tabel 1

Analisis Kesimpulan Akhir Semua Subjek

\begin{tabular}{|c|c|c|c|c|c|c|}
\hline No & $\begin{array}{c}\text { Proses Berpikir } \\
\text { Kreatif menurut } \\
\text { Wallas }\end{array}$ & $\begin{array}{c}\text { Subjek } 1 \\
\left(S_{1}\right)\end{array}$ & $\begin{array}{c}\text { Subjek } 2 \\
\left(S_{2}\right)\end{array}$ & $\begin{array}{c}\text { Subjek } 3 \\
\left(S_{3}\right)\end{array}$ & $\begin{array}{c}\text { Subjek } 4 \\
\left(S_{4}\right)\end{array}$ & $\begin{array}{c}\text { Subjek } 5 \\
\left(S_{5}\right)\end{array}$ \\
\hline 1 & Tahap Persiapan & Baik & Baik & Baik & Baik & Cukup \\
\hline 2 & Tahap Inkubasi & Baik & Bai & Baik & Baik & Baik \\
\hline 3 & Tahap Iluminasi & Baik & Baik & Baik & Kurang & Kurang \\
\hline 4 & Tahap Verifikasi & Baik & Cukup & Baik & Kurang & Kurang \\
\hline \multicolumn{2}{|c|}{$\begin{array}{c}\text { Kesimpulan hasil akhir } \\
\text { semua subjek }\end{array}$} & Tinggi & Tinggi & Tinggi & Sedang & Rendah \\
\hline
\end{tabular}

Dikatakan baik apabila peserta didik dapat menjawab soal dan pertanyaan wawancara yang sesuai dengan pertanyaan masing-masing tahap yang ditentukan dengan benar. Dikatakan cukup apabila peserta didik menjawab soal dan pertanyaan masing-masing tahap yang sudah ditentukan dengan benar tetapi masih ada sedikit yang belum terjawab. Dikatakan kurang apabila peserta didik tidak mampu menjawab soal dan pertanyaan dengan benar.

Kesimpulannya yaitu setiap peserta didik memiliki proses berpikir kreatif yang umumnya berbeda-beda, hal itu dapat disimpulkan menjadi (1) Semua peserta didik yang menjadi subjek mampu mempersiapkan diri untuk menyelesaikan masalah matematika dengan cara mengaanalisis soal kedalam bentuk gambar, (2) Pada tahap inkubasi, semua peserta didik dianggap mampu dalam memperoleh inspirasi yang merupakan titik mula dari suatu gambar yang diaplikasikan kedalam sebuah proses berupa tulisan dengan proses yang benar dan bertahap, (3) Pada tahap iluminasi, ketiga peserta didik dianggap mampu mendapatkan sebuah pemecahan masalah yang diikuti dengan munculnya inspirasi dan ide-ide yang mengawali dan mengikuti munculnya inspirasi dari jawaban yang mengarah kedalam jawaban yang benar, (4) Pada tahap verifikasi, sebagian peserta peserta didik ini dianggap mampu menguji atau memeriksa pemecahan masalah tersebut dengan hasil jawaban dan kesimpulan yang benar. Pemecahan masalah 
yang dilaksanakan oleh peserta didik umumnya terbilang merupakan pemecahan masalah open ended yang terbilang baik karena mereka pada umumnya mampu mengerjakan soal melalui suatu jawaban dengan proses dari berbagai macam alternatif cara, apabila proses itu benarmmaka hasilnya pasti mendapatkan hasil yang sama dengan jawaban yang pastinya benar.

Self-regulated learning peserta didik umumnya tergolong baik karena pada umumnya pada saat soal tersebut dikerjakan peserta didik dianggap mampu memahami dan menjawab hal-hal yang penulis tanyakan, jadi dapat dikatakan umumnya mereka memiliki self-regulated learning yang baik karena tidak adanya ketergantungan dengan peserta didik yang lain dalam menjawab soal ataupun menjawab pertanyaan dari penulis.

\section{Referensi}

Levav-Waynberg, A. \& R. Leikin. (2009). Multiple Solution for a Problem: a Tool for Evaluationof Mathematical Thinking in Geometry. Proceedings of CERME 6, January 28th-February 1st 2009 (online). (http://ife.enslyon.fr/publications/ editionelectronique/cerme6/ wg5-11-levav-leikin.pdf diakses pada 02-03-2015).

Martin. M.O. 2009. Convergent and Divergent Thinking. [Online]. Tersedia: http:www.conptinguind.com/conver gen-divergen-creativity-thinking. [30 Sepetember 2019].

Moleong, L. J. (2017). Metodologi Penelitian Kualitatif, Edisi Revisi. Bandung. Remaja Rosdakarya

Munandar, U. (2012). Pengembangan Kreativitas Anak Keberbakatan. Jakarta: Rineka Cipta

Nabie, M.J., Akayuure, P., \& Sofo, S. (2013). Integrating Problem Solving and Investigations in Mathematics.International Journal of Humanities and Social Science, 3 (15): 46-56

Setiyani. (2013). Profil Berpikir Kreativ Mahasiswa Program Studi Pendidikan Matematika FKIP UNP yang Berkemampuan Logika Tinggi dalam Pemecahan Masalah Open Ended. Prosiding Seminar Nasional 2013.

Siswono, T . E. Y. (2010). Penjenjangan Kemampuan Berpikir Kreatif dan Identifikasi Tahap Berpikir Kreatif Siswa dalam Memecahkan dan Mengajukan Masalah Matematika. Jurnal Pendidikan Matematika "Mathedu" 3(1).

Siswono, T . E. Y. (2012). Penjenjangan Kemampuan Berpikir Kreatif dan Identifikasi Tahap Berpikir Kreatif Siswa dalam Memecahkan dan Mengajukan Masalah Matematika. Jurnal Pendidikan Matematika "Mathedu" 3(1).

Subanji. (2013). Pembelajaran Matematika Kreatif dan Inovatif. Malang: Universitas Negeri Malang. Thiagarajn

Sugiyono. (2011). Metodologi Penelitian Kuantitatif, Kualitatif dan R\&D. Bandung: Alfabeta

Wessels, H. (2014). Levels of Mathematical Creativity in Model-Eliciting Activities. Journal of Mathematical Modelling and Application, 1 (9): 22-40.

Williams, G. 2007. Classroom Teaching Experiment: Eliciting Creative Mathematical Thinking. Journal for the Psychology of Mathematics Education, 4 (1): 257-264. 